Copyright (C) 2015 by Academic Publishing House Researcher

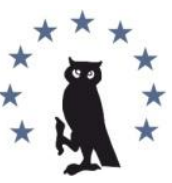

Published in the Russian Federation

European Researcher

Has been issued since 2010.

ISSN 2219-8229

E-ISSN 2224-0136

Vol. 92, Is. 3, pp. 208-213, 2015

DOI: $10.13187 /$ er.2015.92.208

www.erjournal.ru

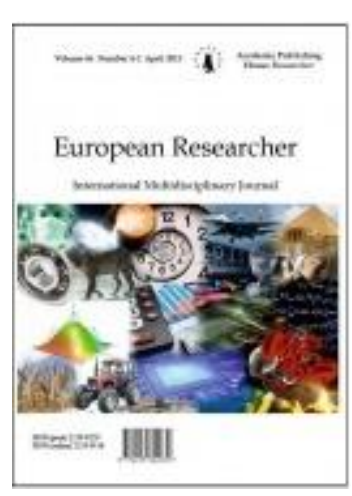

UDC 37.01:81'243

\title{
Cross-cultural Communication as a Way of Achievement of Cross-cultural Communicative Competence
}

\author{
${ }^{1}$ Olga A. Andreyeva \\ ${ }^{2}$ Sholpan K. Tuleubayeva \\ 3 Anna A. Ganyukova \\ ${ }_{4}^{4}$ Zhuldyz M. Tentekbayeva
}

${ }^{1-4}$ Karaganda state university named after academician E.A.Buketov, Kazakhstan
${ }^{1}$ Senior teacher
E-mail: post1976@mail.ru
${ }^{2}$ Senior teacher
E-mail: bekadil.73@mail.ru
3 Senior teacher
E-mail: aneta.2011@mail.ru
4 Senior teacher
E-mail: zhuldyz_83@mail.ru

\begin{abstract}
In this article authors made an attempt to consider a question of cross-cultural communication as a way of achievement of cross-cultural communicative competence. In the process of Kazakhstan entry into the world community in several plans at once - economic, social and cultural - the need for the highly qualified specialists who know foreign language at the productive level, i.e. capable to conduct communication in foreign language and who have linguocultural knowledge increases. For achievement of this purpose it is necessary to consider features of students' training which are determined by the needs of society for the improvement of their education quality, and dynamism of social phenomena demands from the future specialists constant increment of knowledge.
\end{abstract}

Keywords: culture; communication; interaction; cross-cultural interaction; cross-cultural communication; communicative competence; activity approach; professional education.

\section{Introduction}

Numerous definitions of the term "culture" which exist in science, allow to allocate the main thing. Culture is the essential characteristic of the person which is connected with his ability to purposeful and systematic transformation of the world around, "culture is an integral way of life of the whole people" [1]. During it the person creates the artificial world of things, symbols, communications and human relations. Everything that is made by the person or has the relation to him is a part of culture. The most part of information on the world around comes to the person through the linguistic channel; therefore we live more in the world of concepts created for 
intellectual, spiritual and social needs, than in the world of things and subjects. The huge share of information comes to us through the word, and the success of the person in society depends on how well he masters the word, and not so much in respect of the culture of speech, as in ability to get into secrets of the language.

Therefore communication and interaction are the most important part of human life, so, and part of culture. Emphasizing their importance, many researchers equate culture to interaction (communication). The leading American psychologist, the author of a number of works on crosscultural communication E.Hall claimed that culture and communication are identical concepts. Basing on it, many western scientists figuratively imagine the culture in the form of iceberg in the basis of which, cultural values and norms lie, and top is the behavior of the person which is based on them and shown first of all in communication with other people [2].

\section{Materials and methods}

A.A.Leontyev, the famous Russian psychologist and linguist, pointed out in his works that for activity of communication existence of the need for communication changing into the reason is obligatory. The communicative purpose of dialogue is some desirable result for the achievement of which these or those actions from the initiator of the communication (speaker) are taken. The most widespread way of successful communication achievement, i.e. the communicative purpose, according to A.A.Leontyev, is the way through meanings. "We select the words and phrases and we organize them in the statements at various levels so that in the process of perception of the speech by the recipient - in more or less mediated way - desirable shift in its semantic field was carried out" [3]. And here first of all, there is a problem of meaning and sense on which the result of communication considerably depends - whether it will be successful or not.

\section{Discussion of results}

Cross-cultural communication has own regularities which radically influence interaction of subjects of such communication.

For the implementation of productive cross-cultural communication, the language personality has to possess cross-cultural competence. Cross-cultural competence is an ability which allows the language personality to go beyond the own culture and to gain qualities of a mediator of cultures, without losing own cultural identity.

In the process of cross-cultural communication a peculiar code - the foreign language - is uniform for interlocutors, but thus the systems of language meanings and speech forms are various as they are defined by cultural accessory of each of interlocutors.

Cross-cultural communication is a communication of the language personalities belonging to various linguocultural communities. Thus, it becomes clear that for successful communication with carriers of other languages it is necessary to master not only a verbal code (foreign language), but also extra code, background knowledge. Therefore, the communicative failures interfering to communication can be caused not only by ignorance (or insufficient knowledge) of a code (language), but also by the absence of extra code knowledge. So the knowledge of cultural features can positively influence the development of cross-cultural relations, helping to reduce the frequency of communicative failures [4].

Now the problem of cross-cultural communication is in the center of attention of pedagogical science. For the future experts, for graduates of educational institutions the formation of ability and skills of communication in the foreign-language social environment is significant. Profound knowledge of basic lines of other cultures gives the necessary understanding by means of which it is possible to approach communication with representatives of other cultures more intelligently.

Cross-cultural communication is considered in works of such scientists, as A.I.Kravchenko, S.G.Ter-Minasov, N.G.Bagdasaryan, V.I.Maximova and others [5, 6, 7, 8].

Today it becomes more and more obvious that the mankind develops on the way of interrelation and interdependence expansion of various countries, people and their cultures. Cultural features of different people make the question of cultural identity and cultural distinctions more actual. The cultural diversity of modern mankind increases and the people who comprise it find more and more resources to keep and develop their cultural image. 
The communicative part of communication is connected with revealing of specifics of information process between people partners as active subjects, i.e. taking into account the relations between partners and their policy, purposes and intentions that leads not just to "movement" of information, but also to specification and enrichment of that knowledge, data, opinions which people exchange. Communication represents creation of the general strategy of interaction. Means of communicative process are various sign systems, first of all it is the speech [8].

In the sociological encyclopedic dictionary, communication is an interaction of individuals or social groups consisting in face-to-face communication satisfying the needs of the person in contacts with other people by activity, skills, abilities, experience, information [9].

Thus, having considered cross-cultural communicativeness briefly, that is in the center of attention of various sciences, it is possible to draw the conclusion that particular regularities, that should be mastered, are the cornerstone of cross-cultural communication. It is necessary to approach more competently to the communication with representatives of other cultures, in advance to examine features of national lines depending on what country the person is situated; to master special language discourse strategies when communicating with foreign language partners.

Integration of Kazakhstan into world educational and information space is interfaced to searching new ways of formation of the modern expert capable to be guided freely in the polycultural world, understanding its values and meanings, embodying them in worthy exemplars of civilized behavior in the course of interaction with representatives of other professional communities both in our country, and at the international level.

These problems, refracting through the context of globalization and cultural dynamics, assume formation the ability to be guided in the world professional sphere by the modern expert. One of the tools providing achievement of this purpose is cross-cultural communication that is interaction of representatives of various cultures.

Acquisition of cross-cultural communicative competence which represents the functional abilities to understand views and opinions of representatives of other cultures, to correct the behavior, to overcome the conflicts in the course of communication, to recognize the right for existence of various values, behavior norms becomes the most demanded for the modern expert. It creates the basis for professional mobility, preparation for quickly changing living conditions, acquaints the expert with standards of world achievements, increases possibilities of professional self-realization on the basis of communicativeness and tolerance [10].

The main task of the foreign language course at high school has been and stayed as follows "to teach students in practical mastering a foreign language". However, in new economic conditions the essence of the concept "practical mastering" changed considerably. Here, not only language of concrete specialty is included, but also business language, and, the most important is the ability to apply language differentially in the varying situations of business communication, knowledge of culturological aspect, i.e. formation of the linguistic personality of future expert.

The course "Business foreign language" comprises the wide range of the problems concerning national culture, traditions, business etiquette, language. The main difficulties are usually concluded in the fact that students are not familiar with the standard cultural standards of business communication in the foreign-language countries. The formulas of business etiquette, which entered into the English language long ago, for example, have no parallel compliances in Russian and are hardly perceived by its native speakers. And the issue here is concluded not so much in complexity of assimilation of a foreign language, as much in distinctiveness of national mentality of the developed capitalist countries having a vast experience of business communication which not only forms national cultural stereotypes but also promotes establishment of economic relationship.

The most trivial distinctions in the social linguistic models can lead to misunderstanding and even to have more serious consequences. Grammatical or phonetic mistakes in the speech testify only that the person doesn't know a foreign language well enough. In turn, these mistakes cause particular feelings and emotions in participants of dialogue (surprise, indignation, mistrust, etc.) [11].

The academic syllabus on the discipline "Foreign language" for nonlinguistic specialties of higher education institutions assumes the activity approach based on comprehension of a language as means of communication in a particular situation, in a particular context, with a particular communicative task, i.e. speech activity is carried out in a wide social context. 
The following competences are in the cornerstone of mastering a language: the common competence representing the sum of knowledge, skills and characteristics which allow it to reproduce speech; the communicative competence allowing to perform action with use of language means.

The communicative competence consists of linguistic, social linguistic and pragmatic components, each of which includes all categories of the common cross-cultural competence of the person.

The special place in the conditions of interaction of the designated components is taken by the social linguistic component which is connecting one between communicative and other types of competences, emphasizing the importance of cultural component for cross-cultural communicative competence.

Due to the focus on social norms (rules of good manners, norm of communication between representatives of different generations, genders, public groups, language assimilation of the particular rituals accepted in this society) the social linguistic component has a great influence on language registration of communication between representatives of different cultures. The social linguistic component of communicative competence is related to language aspect of social cultural competence.

Social linguistic competence in the relation of a dialect and accent includes ability to distinguish language features of social groups, the places of residence, origins, occupation. Such features occur at the level of lexicon, grammar, phonetics, speech manners, paralinguistics, language of gestures [12].

One of features of communicative oriented vocational teaching a foreign language is connection of linguistic competence (assimilation of language norms) and communication (interactive competence) as primary activity in the "person-person" model [13].

Many difficulties when teaching a foreign language cause such situations of business communication as making personal contacts, writing business letters, conversations by phone, holding meetings and negotiations, etc.; native speakers of the Russian language have restricted knowledge of strategy of communicative expansion of the above-named situations at the cognitive level, they do not master language signals of their structuring and interaction in them. This circumstance forces to pay special attention to assimilation by students and listeners of situations of business communication, development of skills of adequate orientation in the plans communicating in those social and professional values from which carriers of other culture proceed.

The typical situations arising in business communication in foreign-language society have to become a subject of cognitive activity of the students learning a foreign language. Formation of cross-cultural communicative competence, knowledge of the world of professional communication and its rules, development of skills of identification and generation of speech models of diverse situations of business cooperation is teaching strategies of professional communicative impact on the partner. It is reached by modeling of situations of professional cooperation in which the foreign language acts as the instrument of social interaction of the person and professional foreignlanguage collective in educational process, all changes of social cultural factors influencing hierarchy of meanings and values in a picture of the world of the person, its mentality, pragmatic settings are reflected in it. It is not only about professional focused tutoring, but also first of all about teaching special speech models, correction of professional discourse, realization of strategy of communicative interaction in each situation directed on reaching an agreement in the solution of practical tasks [14].

Interactive strategies of professional discourse have probably the universal character in the mode of cooperative, symmetric communication that, however, does not exclude originality of cognitive structuration of models and macrostrategies in professional interaction of various societies. Acquaintance to cross-cultural features of behavior of representatives of a speech community in business situations finishes the formation of professional interactive competence of the secondary language person [15].

\section{Conclusion}

Proceeding from the tasks designated above, it is possible to claim that cross-cultural communicative competence includes the whole complex of communicative components and 
represents process of mastering knowledge of cultural diversity of world around of the countries the co-studied languages and about the relationship between cultures in the modern polycultural world, and also formations of the active living position and abilities to interact with representatives of the different countries and cultures according to the principle of culture dialogue.

\title{
References:
}

1. Williams K., Culture, Fontana, London, 1981.

2. John E. Hall The Silent Language. New York: Doubleday, 1959.

3. Leontyev A.A. Psychology of speech communication: Abstract of doctor dissertation. M, 1975.

4. Kramsch C.J. The privilege of the intercultural speaker // Byram M., Fleming M. (eds.) Language learning in perspective: approaches through drama and ethnography. New York: Cambridge University Press, 1998 [p. 27]

5. Kravchenko of A.I. Culturology: handbook for higher education institutions. M.: Academic Project, 2002. P. 24.

6. Ter-Minassov S.G. Yazyk and cross-cultural communication. M., 2000. 624 p.

7. Bagdasaryan I.I. Culturology. M.: High school, 2004. 709 p.

8. Maximova V.I. The Russian language and speech culture. M.: Gardariki, 2004. 408 p.

9. Ossipov G.V. Sociological encyclopedic dictionary. M.: Norm, 2004. 480 p.

10. Smirnova O.O. Development of foreign-language communicative abilities at the faculty of journalism//Linguistics on the XX century outcome: Results and prospects. Theses of the international conference. M.: MSU, 1995. P. 477-479.

11. Buram M., Teaching and assessing intercultural communicative competence, Clevedon: Multilingual, Matters Ltd., 1997, [p. 21-22]

12. Edward T. Hall. Hidden Differences: Studies in International Communication. Hamburg, Crunder\& Jahr., 1985.

13. Bossova L.M. Language as means of cross-cultural communication//the Conceptual world picture and interpretive field of the text from the viewpoint of linguistics, journalism and communication study: (collection of materials of the Russian scientific practical conference, on June 20-23, 1999). Barnaul, 2000. P. 88-94.

14. Khaleeva I.I. Bases of the theory of training in comprehension of the foreign-language speech. M.: High school, 1989.

15. Adar M., Language Shock: Understanding the culture of conversation, William Merroy and company, Inc., New York, 1994, [p. 118]

\section{УДК 37.01:81'243}

\section{Межкультурное общение как способ достижения межкультурной коммуникативной компетенции}

\author{
${ }^{1}$ Ольга Александровна Андреева \\ ${ }^{2}$ Шолпан Каленовна Тулеубаева \\ 3 Анна Алексеевна Ганюкова \\ 4 Жулдыз Мухамедгалиевна Тентекбаева
}

\author{
1-4 Карагандинский государственный университет имени Е.А.Букетова, Казахстан \\ 100о0о, Караганда, ул. Толепова, 9-10 \\ ${ }^{1}$ Старший преподаватель \\ E-mail: post1976@mail.ru \\ ${ }^{2}$ Старший преподаватель \\ E-mail: bekadil.73@mail.ru \\ ${ }_{3}$ Старший преподаватель \\ E-mail: aneta.2011@mail.ru \\ ${ }_{4}^{4}$ Старший преподаватель \\ E-mail: zhuldyz_83@mail.ru
}


Аннотация. В данной статье авторами предпринята попытка рассмотреть вопрос межкультурного общения как способа достижения межкультурной коммуникативной компетенции. По мере вхождения Казахстана в мировое сообщество сразу в нескольких планах - экономическом, социальном и культурном - возрастает потребность в высококвалифицированных специалистах, владеющих иностранным языком на продуктивном уровне, то есть способных вести коммуникацию на иностранном языке и обладающих лингвосоциокультурными знаниями. Для достижения данной цели необходимо учитывать особенности подготовки студентов, которые детерминированы потребностями общества в повышении качества их образования, а динамизм социальных явлений требует от будущих специалистов постоянного приращения знаний.

Ключевые слова: культура; коммуникация; общение; межкультурное общение; межкультурная коммуникация; коммуникативная компетенция; деятельностный подход; профессиональное обучение. 